Reactions to the Market 



\title{
Reactions to the Market
}

Small Farmers in the Economic Reshaping of

Nicaragua, Cuba, Russia, and China

\author{
Laura J. Enríquez
}

The Pennsylvania State University Press

University Park, Pennsylvania 
Published in cooperation with the Rural Sociological Society.

\section{Library of Congress Cataloging-in-Publication Data \\ Enríquez, Laura J.}

Reactions to the market : small farmers in the economic reshaping of Nicaragua, Cuba, Russia, and China / Laura J. Enriquez.

p. cm.-(Rural studies series)

Includes bibliographical references and index.

Summary: "Analyzes the reaction of existing and former socialist countries to neoliberalism.

Examines economic transitions in agriculture and the reconfiguration of socialism in Russia,

China, Nicaragua, and Cuba"-Provided by publisher.

ISBN 978-0-271-036r9-9 (cloth : alk. paper)

I. Farms, Small-Former communist countries.

2. Land reform-Former communist countries.

3. Former communist countries-Economic policy.

4. Land reform-Former communist countries.

I. Title.

$$
\begin{gathered}
\mathrm{HD}_{1333} \cdot \mathrm{F}_{57} \mathrm{E}_{57} \quad 2010 \\
338.109 \mathrm{III}^{\prime} 7-\mathrm{dc} 22 \\
2009030850
\end{gathered}
$$

Copyright (C) 2010

The Pennsylvania State University

All rights reserved

Printed in the United States of America

Published by

The Pennsylvania State University Press,

University Park, PA 16802-1003

The Pennsylvania State University Press

is a member of the Association of American University

Presses. It is the policy of The Pennsylvania State University

Press to use acid-free paper. Publications on uncoated stock

satisfy the minimum requirements of American National

Standard for Information Sciences-Permanence of Paper

for Printed Library Material, ANsI Z39.48-I992.

This book is printed on Natures Natural, which contains $50 \%$ post-consumer waste. 